\title{
'n Bestuurshulpmiddel vir doelmatige en doeltreffende kerkbestuur: 'n Generiese perspektief vir 'n makro-gemeente
}

\author{
A A van den Berg ${ }^{1}$ \\ Departement Praktiese Teologie \\ Universiteit van Pretoria
}

\begin{abstract}
A management tool for efficient and effective church management: A generic perspective for a macrocongregation

This article examines the place and function of project management as a generic management tool in the church and the potential solution it has to offer in respect of congregation management and ministry. "Project" and "project management" are defined and contextualised within a church environment. The project management process is put in the context of a project management system and of the congregation and its relevant functions. Project management consists of five generic phases namely, project initiation, project planning, project execution, project control and project closure. The project manager is provided with an overall picture of the project management process, with specific reference to its compilation and workings. The discussion in the article includes the management of the human dimension of the project management process.
\end{abstract}

\section{INLEIDING}

In dié artikel word die generiese aspekte van projekbestuur met die oog op 'n bestuursraamwerk, behandel. Die hoofdoel van hierdie artikel is om ' $n$ geïntegreerde en generiese prosesraamwerk aan te beveel wat in enige makrogemeente, deur ' $n$ projekbestuurder en lidmate gebruik kan word. Die artikel stel 'n stap vir stap projekbestuursraamwerk voor wat gebruik kan word

\footnotetext{
${ }^{1}$ Hierdie artikel is 'n verwerking van 'n gedeelte uit die PhD-proefskrif, "'n Projekbestuursmodel vir doelmatige en doeltreffende gemeentebestuur", (2002), Fakulteit Teologie, Universiteit van Pretoria. Die proefskrif is voorberei onder promotorskap van prof dr C J A Vos en mede-promotor prof dr J Buitendag.
} 
deur 'n ervare sowel as onervare projekbestuurder om hom/haar op 'n eenvoudige manier met die nodige basiese kennis van die projekbestuursproses te bedien. 'n Belangrike aspek van die raamwerk is dat daar ook aandag aan die menslike dimensie van projekbestuur gegee word.

\section{VERTREKPUNT}

Die uitgangspunt in die artikel is die vormgewing (gestaltegewing) aan 'n doelmatige en doeltreffende bestuursmodel vir 'n makrogemeente. Die vormgewing aan so ' $\mathrm{n}$ bestuursmodel is om projekbestuur as bestuurshulpmiddel van toepassing op kerklike bestuur te maak. Noodwendig moes die volgende vrae beantwoord word: Kan die kerk ('n gemeente) as 'n onderneming geklassifiseer word (Kroon 1995:51-70; vgl ook Van den Berg 1998; Buitendag 1994:2-3)? In watter mate word die gestaltegewing van 'n projekbestuursmodel in die kerk gereflekteer? In watter mate beskik gemeentes (lidmate) oor die nodige kennis tot gestaltegewing van 'n projekbestuursmodel vir die kerk? Die resultaat wat uit bogenoemde bereik is, is om vanuit 'n bestaande situasie (praxis 1) die vormgewing van 'n bestuursmodel voor te stel (praxis 2) - 'n verstelde bediningspraktyk (Smuts 1995:120-182; Heitink 1993:21; Pieterse 1993:12; Pieterse 1991:139).

\section{$2.1 \quad$ Uitgangspunt}

Omdat die Bybel nie vir ons 'n bloudruk gee van hoe die kerklike strukture in die praktyk behoort te lyk nie, die gestaltegewing, is dit belangrik om in die lig van haar identiteit, riglyne neer te lê. Die gestaltegewing moet gevolglik die kerk se identiteit op 'n eietydse wyse vergestalt. Dit sal altyd binne 'n sekere konteks gestalte moet kry (Van der Ven 1993:10-12). Die eie tyd, omstandighede, kultuur en geestesklimaat speel 'n belangrike rol in die gestaltegewing van die kerk. Die kerk moet gevolglik eietyds en relevant wees.

' $n$ Visie en missie van die kerk behoort so geformuleer te word dat dit die mens van vandag raak (Van der Walt 1999:47, 49, 93). Om dit te bereik, is die uitdaging om die kennis en die beginsels van projekbestuur op die kerklike bedieningspraktyk tersaaklik te maak.

Die kerk is in 'n oorgangstyd. Die kerk mag nie swig voor of toegee aan die behoeftes van moderne mense nie. Van der Walt (1999:83) stel dit kategories dat 'n geestelike grondverskuiwing plaaslik en wêreldwyd, besig is om plaas te vind. Hierdie verskuiwing het 'n impak op die politieke, ekonomiese, kulturele, en 
godsdienstige terreine. Die nuwe werklikheidsverstaan, is dié van die postmodernisme. Dit is nie die bedoeling van hierdie artikel om 'n uitvoerige redenasie oor postmodernisme te lewer nie. Die doel is eerder om die kerk na aanleiding van die verskillende sienings in 'n postmoderne tyd, te posisioneer. Die kerk behoort dan in dié tyd so bestuur te word, dat sy in staat sal wees om aan post-moderne mense antwoorde te verskaf sonder om self postmodernisties te word (Van der Walt 1999:84, 86, 91; Rossouw 1995:75-91).

\section{DIE PRAKTYK}

Dit is seker debatteerbaar of projekbestuur ontwikkel is as gevolg van algemene en strategiese bestuur se onvermoë om komplekse probleme te hanteer. Wat egter nie debatteerbaar is nie, is die feit dat vandag se komplekse probleemoplossings al hoe meer gesetel is in 'n geïntegreerde, multi-funksionele stelselontwikkelingsbenadering. Projekbestuur is een van die kragtigste bestuurstegnieke, indien dit korrek aangewend word, om hierdie komplekse, geïntegreerde stelselontwikkelingsproses te bestuur ten einde die organisasiedoelwitte te bereik (PMBOK 2000). Voordat projekbestuur bespreek word, is dit egter noodsaaklik om die karakteristieke van 'n projek te identifiseer, aangesien dit lig op die karakter van projekbestuur werp.

\section{1 'n Projek}

'n Projek kan volgens Knutson \& Bitz (1991:1) gedefinieer word as 'n unieke poging om 'n nuwe of verbeterde produk of diens, wat aan sekere gebruikerspesifikasies en betrokke standaarde moet voldoen, daar te stel. Hierdie poging moet egter binne die volgende projekparameters voltooi word, naamlik 'n vaste tyd, koste, beskikbare menslike hulpbronne, en beperkte bates. 'n Projek is dus 'n goed georganiseerde stelselontwikkelingsproses met ' $n$ vasgestelde begindatum, einddatum en eindproduk of lewerbare (die diens) (PMBOK 2000:6; Smuts 1995:13-15).

Projekte is gevolglik die wyse waarop nuwe produkte of dienste na die "besigheidsmark" gebring word. Projekte is die voertuie vir 'n organisasie (makrogemeente) se groei en vooruitgang. Archibald (1976:3, 18-19) definieer 'n projek as 'n komplekse stelselontwikkelingspoging, met die volgende kenmerke: 'n proses met 'n stelsellewensiklus, gewoonlik minder as 3 jaar; met 'n goed gedefinieerde doelwit, skedule en begroting; wat uit interafhanklike take bestaan, en wat deur verskillende funksies of divisies uitgevoer word. 
'n Projek kan gevolglik as 'n groep organisasiehulpbronne wat tydelik saam ingespan word om 'n spesifieke organisasiedoelwit te bereik, beskou word. Dit is ' $n$ eenmalige proses wat gewoonlik binne ' $n$ vaste begroting en tyd plaasvind. ' $n$ Tendens wat dikwels aangetref word is dat die term "projek" in baie organisasies sonder die nodige oordeel gebruik word. Mense verwys graag na hul take as projekte. Dit is belangrik dat 'n taak of ontwikkelingspoging eers aan die hand van bogenoemde definisies getoets word, ten einde te bepaal of dit werklik 'n projek is. Indien dit die geval is, kan projekbestuur as 'n bestuurstyl vir die taak oorweeg word.

\subsection{Projekbestuur}

Projekbestuur is 'n groeiende, evolusionêre dissipline wat die stelselontwikkelingsprosesse integreer met die prosesse van projekbeplanning, projekbeheer, die inisiëring van voorkomende asook regstellende aksies, konfigurasiebeheer en kwaliteitsversekering. Projekbestuur maak voorts gebruik van die stelselbenadering tot bestuur deur funksionele personeel (vertikale hiërargie) aan projekte toe te wys (horisontale hiërargie) (Knutson \& Bitz 1991:2; Kerzner 1992:4).

Uit bogenoemde definisies is dit duidelik dat projekbestuur die volgende take insluit: Die samestelling van 'n projekspan met die nodige kundigheid om die projek uit te voer. Die definiëring van wat met die projek bereik, geskep of ontwikkel moet word. Die beplanning van die projek. Die beheer oor die projek wat die toepassing van die nodige veranderingsbestuur insluit, met inbegrip van die kwaliteitsversekering wat met die uitvoer van die projek vereis word. Die verantwoordelikheid om die projek binne die gegewe tyd en koste te voltooi. Projekbestuur is uit bogenoemde dus die bestuursdissipline gemoeid met die beplanning, skedulering en beheer van nie-roetine aktiwiteite binne ' $n$ vaste tyd en hulpbronvermoë, om 'n bepaalde doelwit te bereik (Kerzner 1998:2-5, 69, 72; Van der Waldt \& Knipe 1998:58).

Wanneer is projekbestuur suksesvol? Eerstens moet die projek suksesvol geïmplementeer word. Dit impliseer dat daar aan die volgende projekdoelwitte voldoen moet word naamlik, dat die projek: binne die gegewe tyd, binne die gegewe koste, met die gebruiker se tevredenheid (ooreengekome standaarde), en met die effektiewe en doelmatige aanwending van hulpbronne tot die projek se beskikking, afgehandel word. Bogenoemde verteenwoordig die tradisionele kriteria vir die bepaling van 'n projek se sukses. Die siening word 
deur Kerzner (1992:6) gedeel wat projeksukses soos volg definieer en die tradisionele kriteria ietwat uitbrei. Die projek moet voltooi word: binne die toegelate tyd, binne die begrote koste, met 'n aanvaarbare vlak van gebruikerstevredenheid en volgens die spesifikasies, met gebruiksaanvaarding deur die gebruiker, met minimum, gesamentlik ooreengekome veranderings aan die omvang van die projek sonder om die hoofvloei van die organisasie se besigheid te benadeel of daarop inbreuk te maak, sonder om die korporatiewe kultuur van die organisasie te verander (Van Wyk 1995:16-19).

Die feit dat 'n projek ' $n$ tydelike proses is met ' $n$ vaste begin- en einddatum, impliseer dat projekte en ook projekbestuur 'n stelsellewensiklus moet hê. Volgens Kerzner (1992:82) sal begrip en kennis van die fases van die projekbestuurstelsellewensiklus bestuur in staat stel om beter beheer oor die totale organisasiehulpbronne uit te oefen in die bereiking van die projek- en organisasie doelwitte. Hy stel die volgende stelsellewensiklus vir projekbetuur voor: Konsepsuele fase; Inisiëring (Definisie fase); Beplanning of Ontwikkelingsfase; Operasionele fase (Implementering); Ontbindingsfase (Afsluiting); Kontrole (deurlopende aksie oor al die fases). Hierdie fases van projekbestuur is altyd teenwoordig, maak nie saak wat die aard of tipe projek is wat uitgevoer word nie. Dit kan dus beskou word as die generiese lewensiklus van projekbestuur.

Projekbestuur word in dié artikel gesien as 'n generiese proses wat enige komplekse ontwikkelingsproses kan bestuur, soos byvoorbeeld: die bou van 'n pad, die bou van 'n gebou, die ontwikkeling van 'n produk, die ontwikkeling van 'n dienstestelsel vir makrogemeentes ensomeer. Die projekbestuurder is die persoon (lidmaat) met die gawe van bestuur wat die metodiek behoort toe te pas in die uitvoering van die projek (Kerzner 1998:10-16; Deacon 1997:3). Die resultaat van so hierdie benadering is 'n stap vir stap projekbestuursmetode of prosesmodel vir gemeentelike gebruik. Die prosesmodel vir gemeentes is so ontwikkel dat ervare én onervare bestuurders dit stapsgewys sal kan volg.

\section{TOEGEPASTE PROJEKFASES}

Die generiese projekfases (projekbestuursraamwerk): Projekinisiëring; Projekbeplanning; Projekimplementering; Projekkontrole en beheer en Projekafsluiting vorm die grondslag waarop die aanbevole projekbestuursprosesmodel gebou is (PMBOK 2000:11-15). Hierdie projekfases kom in alle projekbestuursprosesse voor en word altyd geïnisieer deur die bepaling van ('n) behoefte(s) in 'n bestuursomgewing. Hierdie fases is die grondslag waarop enige 
projekbestuursproses en -model gebou word (Kerzner 1998:73-81; Oosthuizen 1994:42-44). Die menslike dimensie, wat onafskeidbaar van die projekbestuursproses is, word as ' $n$ bykomende sleutelkomponent van die projekbestuursproses beskou. Om hierdie rede is die bestuur van die menslike dimensie bykomend tot die projekfase in die prosesmodel van die projekbestuursproses ingebou.

\subsection{Projekinisiëringsfase}

Die projekinisiëringsfase is die heel eerste fase van die projekbestuursproses en bestaan hoofsaaklik uit die volgende kernprosesse, naamlik: die ontwikkeling van 'n projekidee of -geleentheid, die formulering van die projekversoek deur die gebruiker, die uitvoering van 'n projekseleksieproses ten einde die uitvoerbaarheid van die projek te bepaal, en om die projek formeel goed te keur en te prioritiseer, die aanwysing of aanstelling van 'n bevoegde projekbestuurder, die keuse van 'n geskikte organisasiestruktuur vir die projek, die organisasering van die projekkantoor, en die aanstelling van 'n bekwame projekspan (PMBOK 2000:53; Van der Waldt \& Knipe 1998:71; Adendorff \& De Wit 1997:156-157; Van Wyk 1995:39-66). Hierdie fase word soms voorafgegaan deur 'n behoeftefase. Die behoeftefase kan ook deel vorm van die inisiëringsfase. Vir die doel van hierdie navorsing word dit as 'n pre-projekfase (fase 0) gebruik. Die projekinisiëringsfase gebruik die inligting van die pre-projekfase vir die inisiëring van die projek (Gido \& Clements 1999:21-51; Meredith \& Mantel 2000:39-45).

\subsection{Projekbeplanningsfase}

Die doel van hierdie fase is om die volgende vir 'n gemeente in te sluit: Formuleer en verstaan die projekomvang sodat ' $n$ bepaling gemaak kan word vir die projekdienswerk. Hierdie raming moet binne die gegewe koste, tyd, en standaarde beplan en georganiseer word. Verder behoort alle risiko's bepaal en beplan te word. Beplanning moet insluit dat alle aflewerbares aan die gestelde standaarde voldoen (Dinsmore 1993:115-143; vgl ook PMBOK 2000:42; Van der Waldt \& Knipe 1998:72-76; Adendorff \& De Wit 1997:158; Van Wyk 1995:71-131)

Die volgende beplanningsprosesse word as die kerntaak van die projekbestuurder gesien en beplan die prosesse met die volgende doel: Geïdentifiseerde behoeftes moet verstaan word. Verkry al die belanghebbendes se verbintenis tot die projek en subprojekte. Beding aanvaarding van eienaarskap vir elke dienswerk. Fasiliteer die projekplan deur die volgende aktiwiteite: 
- $\quad$ Verduidelik alle dienswerk per projek deur die werkafbraakstruktuur.

- Verduidelik alle interafhanklikhede van dienste (take) op mekaar.

- $\quad$ Bepaal die tyd en kosteberamings van elke dienswerk (taak).

- $\quad$ Bepaal hulpbronne (lidmate met gawes) per dienswerk.

- $\quad$ Stel die projekskedule(s) vir die hele projek op.

- $\quad$ Stel die finale projekplan saam.

- $\quad$ Administreer die projekplan deur die byhou van 'n projeklêer deur die personeel van die projekkantoor.

- Doen deurlopend verslag deur die projek se status te kommunikeer (Gido \& Clements 1999:182-217; Newbold 1998:101-113).

Die projekskedule is die hulpmiddel wat die projekbestuurder in staat stel om alle hulpbronne doelmatig en doeltreffend aan te wend. 'n Moderne skeduleringsprogram kan gebruik word om die projekbestuurder(s) in staat te stel om hulpbronladings per dienswerk (take) te manipuleer sodat oorbenutting nie plaasvind nie.

\subsection{Projekimplementeringsfase}

Die werklike uitvoering van die projek is die stap vir stap implementering van die projek deur die toepassing van die projekskedule. Die uitvoeringsproses bestaan uit die volgende sub- en verwante projekte, naamlik: Projekbeheer - met doelmatige en doeltreffende prosesse in plek; Kwaliteitsbeheer; Konfigurasiebestuur (Van der Waldt \& Knipe 1998:82-83; Meredith \& Mantel 2000:261-462). 'n Projek kan nie sonder 'n behoorlike beheerstelsel gedoen word nie. Só 'n beheerstelsel vereis die volgende strukture, metodes, aktiwiteite, bestuurstegnieke en dienste (aksies en take):

- $\quad$ Effektiewe rapporteringstrukture.

- $\quad$ Effektiewe rapporteringstegnieke en -metodes.

- $\quad$ Effektiewe statusverslae.

- $\quad$ Effektiewe interpreteringsmetodes van data wat versamel is.

- $\quad$ Effektiewe kwaliteitsversekering.

- Effektiewe konfigurasiebestuur.

Die implementering van die projek beteken dat die beplande dienste en take gedoen word. Dit beteken die inisiëring van die dienswerk op elke projek en dat deurlopende opvolg van vordering op die dienswerk gemonitor word (PMBOK 
2000:46; Van der Waldt \& Knipe 1998:82; Adendorff \& De Wit 1997:158; Van Wyk 1995:145-179). Die gepaardgaande kwaliteitsversekering, konfigurasiebestuur en die neem van regstellende aksies indien nodig, is bepalend vir elke taak (PMBOK 2000:47, 62, 79, 90, 95-102; Van der Waldt \& Knipe 1998:84; Adendorff \& De Wit 1997:158-159; Van Wyk 1995:149-179).

\subsection{Projekafsluitingsfase}

Hierdie is die laaste fase in die projeklewensiklus. Daar word uitgewys dat enige projek eers as afgehandel beskou kan word wanneer dié fase voltooi is. Die afsluiting van die fase vind plaas by die aftekening daarvan deur die projekeienaar (die kerkraad). Die volgende afsluitingsaktiwiteite, wat moet plaasvind ten einde die projek as voltooi te beskou, sal uitgewys word: Die voltooiing van uitstaande take indien nodig; Prestasiebeoordeling - nie noodwendig vir die gemeente nie; Projekevaluering en 'n projekoudit; Die opstel van 'n afsluitingsverslag en die hou van 'n afsluitingsvergadering (PMBOK 2000:117-144; Van der Waldt \& Knipe 1998:85; Adendorff \& De Wit 1997:158; Van Wyk 1995:189-208).

\subsection{Die projekbestuurder}

Die projekbestuurder word uitgesonder as die lidmaat wat deurlopend in al die projekfases betrokke moet wees - 'n oorkoepelende koördineringsfunksie. Van die projekbestuurder sal verwag word om mense (lidmate) deur die projeklewensiklus, te bestuur. Die beginsel van delegering van gesag en verantwoordelikhede deur deelnemende bestuur behoort deurlopend gevolg te word ten einde die doelwitte van elke projek te bereik. Een van die die projekbestuurder se besondere take is die bestuur van die menslike dimensie (Van der Walt 1999:4672; Deacon 1998:3; Kerzner 1998:10-16). Die bestuur van die menslike dimensie bestaan hoofsaaklik uit die saamstel en vorming van 'n projekspan, deur 'n eie spanidentiteit te skep, die projekspan te motiveer, en die konflik op die projek effektief te hanteer (PMBOK 2000:117; Kerzner 1998:267, 349; Cummings \& Worley 1993:540-543).

\section{GEMEENTE AS PROJEKBESTUURSOMGEWING}

Die uitdaging is om projekbestuur op die kerklike praktyk tersaaklik te maak. Die toepassing vind plaas binne 'n gemeente wat as 'n eie onderneming beskou kan word. Die plek en funksie van bestuur in die kerk is nie meer 'n vreemde ver- 
skynsel nie (Van den Berg 1998). Die kerk word in die artikel as 'n onderneming verstaan. Dit is nie meer vreemd om dat bestuursbeginsels op 'n gemeentelike omgewing en situasie van toepassing gemaak word nie. Per slot van rekening is dit ook ' $n$ selfstandige stelsel wat met wigte en teenwigte in balans is en in die samelewing moet kan oorleef. Die basiese beginsel van enige onderneming, naamlik dat dit geld wil maak, nie ten koste van die omgewing nie, maar gekwalifiseerd ten behoewe daarvan, kan ook van die kerk gesê word, hoewel geldmaak nooit ' $n$ doel op sigself kan en mag wees nie ... die kerk bly egter anders, alhoewel nie totaal anders nie (Buitendag 1994).

Die ekonomiese beginsel van die skaarsheid (vraag en aanbod) van 'n produk kan nie op die kerk toegepas word nie. Die produk (dienswerk) wat in die kerk "verhandel" moet word om behoeftes te vervul, is deur God aan die kerk gegee. Die produk (dienswerk) is die verkondiging van die evangelieboodskap van Jesus Christus. Die kerk ontvang dus die produk (dienswerk) van God, maar die mens moet self tot die besef van sy of haar behoefte aan dié produk kom. Die kerk moet dan die produk op die mees kundige wyse aan die mens bemark (Buitendag 1994).

Bestuur, en projekbestuur in die besonder, is die proses waardeur mense as gelowiges in bepaalde gemeentelike dienste, menslike en ander hulpbronne so doelmatig moontlik aangewend word ten einde die (bedienings-) behoefte op elke terrein van die gemeente te vervul, om so die spesifieke gemeentelike doelstellings te bereik. Volgens Lindgren (1965:60) is die handeling in die kerk met die oog op doelmatige kerkbestuur, die betrokkenheid van die kerk by die ontdekking van haar aard (identiteit) en missie. Dit is ook 'n samehorige en omvattende beweging (dienswerk) wat die kerk in staat sal stel om al haar hulpbronne en personeel te benut in die vervulling van die missie van God se liefde (Jesus Christus) vir alle mense.

\section{ONTSLUITING VAN DIE ARGUMENT}

Projekbestuur word as 'n bestuurshulpmiddel vir lidmate as projekbestuurders in konteks geplaas. Die projekbestuursproses word as 'n stap vir stap proses ontwerp en as 'n prosesmodel gemodelleer. Die projekbestuursproses word as deel van die projekbestuurstelsel vir die aangewese projekbestuurder en lidmate binne die gemeente geposisioneer. Dit word gedoen deur die uitvoer van projekbestuursaktiwiteite deur toe te sien dat hulle byvoorbeeld binne tyd, koste en aan gestelde standaarde voldoen; die projekbestuursaktiwiteite krities uit te voer deur 
die volgende vrae deurlopend te vra: Is wat gedoen word nog nodig om te doen bestaan die behoefte nog? Het wat uitgevoer word nog 'n doel - pas dit steeds in by die gestelde doelstelling en doelwitte van die gemeente? Word wat gedoen word, reg gedoen - volgens ooreengekome standaarde en definisies? Is daar nie ander of beter metodes om wat gedoen word, te doen nie - kan die proses dalk verbeter word vir die huidige projek? Die projekbestuurder moet alle projekbestuursaktiwiteite deurlopend tydens die projeklewensiklus krities evalueer en indien nodig, dit by die betrokke gemeentesituasie(s) aanpas (aangepas uit Van Wyk 1995).

\section{DIE UNIEKE BESTUURSIDENTITEIT VAN 'N GEMEENTE}

Die kerk of gemeente is 'n komplekse samelewingsverband met 'n unieke identiteit, taak en manier van doen wat binne 'n bepaalde konteks moet leef - die (bestuurs) omgewing. Daar word van die gemeente met haar uniekheid verwag om nader aan dié ideaal te kom deur: ' $n$ visie (identiteit) en missie (taak/dienste/ bedieninge) te formuleer en dan kreatief te verwerklik in die konteks waarin sy leef, sodat lidmate deur die Woord en Gees vernuwe word tot 'n lewensvisie wat gestalte vind in 'n nuwe lewenswandel (Van der Walt 1999:47, 49, 93).

\section{DIE NUWE WERKWYSE}

Al die projekbestuursprosesse en hulle onderskeie subprosesse word binne die konteks van 'n projekbestuurstelsel geplaas. Die projekbestuurstelsel word weer binne die konteks van die gemeente en die relevante gemeentefunksies geplaas. Projekbestuur, die projekbestuurstelsel en die projekbestuursproses is dus binne die gemeente geposisioneer. Hierdie projekbestuursprosesmodel behoort selfs onervare lidmate in staat te stel om 'n geheelbeeld van projekbestuur te kry en toe te pas.

\subsection{Keuse van 'n benadering}

Kerkbestuur is nie maar net 'n losstaande handeling nie, maar verteenwoordig 'n doelmatige handeling wat daarop ingestel is om die doelstellings en doelwitte wat deur deelnemende besluitneming (Greenleaf 1991:94-97; Wagner 1984:87-89) geneem is, te bereik. Die verhouding tussen kerk en samelewing moet daarom in perspektief geplaas word. Die kerk is deel van hierdie samelewing (wêreld) en moet haarself nie net hierin vind nie, maar baie duidelik posisioneer. Die kerk sal 
haarself as hermeneutiese brug moet posisioneer en noodwendig ' $n$ nuwe kerkmodel formuleer (Dingemans 2000:258-30; Heitink 2000:260-274).

Die praktykteorie waarna getreef word, as die resultaat van die betoog, is hoe die kerk haarself moet organiseer om aan haar Godgegewe doel te beantwoord. Dit is die teologiese teorie wat die grondslag van die praktykteorie vorm. Die bedieningspraktyk is gevolglik 'n resultaat van bogenoemde formulering en verteenwoordig die werklike situasie van hoe ' $n$ bepaalde geloofsgemeenskap dan (nuut en bestuurbaar) sal funksioneer (Heitink 2000:260).

Die vernuwingsproses behels die volgende kernaksies: Die bestudering van die Woord van God om vas te stel wat die kerk in haar wese is. Die vraag wat gevra moet word, is hoe die gemeente georganiseer moet word om die nuwe praktykteorie te akkommodeer. Dit is die formulering (daarstel) van 'n raamwerk wat as bloudruk moet dien vir gemeentebestuur. Bestuur behoort dan 'n strategiese sessie te belê (deelnemende besluitneming). Elke gemeente behoort 'n eie strategiese beplanninsproses te deurloop weens die verskil wat daar tussen onderskeie gemeentes bestaan. Dit is nie moontlik om 'n generiese praktykteorie daar te stel wat oral presies dieselfde sal werk nie.

\section{STRATEGIE VIR 'N GEMEENTELIKE PRAKTYKTEORIE}

In navolging van Vos (2000:181-182), gaan hierdie navorsing uit van die Koninkryksperspektief. Die kerk moet haar opdrag om kerk in en vir die wêreld hierdie wêreld - te wees, met entoesiasme aanvaar. Hierdie aanvaarding beteken om vir God "ja" te sê teenoor die wêreld. Dit plaas die kerk in Koninkryksperspektief. In hierdie posisie van die ruimte van die Koninkryk kan die kerk deelneem aan die gesprek oor waardes en norme, reg en verkeerd, geweld en armoede. Die individu kan nou ruimte vir sy of haar persoon vind en die kerk word 'n ruimte vir die gemeenskap. Die kerk aanvaar haar sosiale en publieke verantwoordelikheid en word ' $n$ ruimte vir bestaansvrae. Met hierdie vertrekpunt is dit nodig dat die kerk haarself verder posisioneer om te beantwoord aan haar bestaansdoel. Die identiteit van die kerk word gevolglik bepalend vir die argument

Identiteit loop hand aan hand met introspeksie. In die kerk gaan dit oor geestelike selfondersoek. Selfondersoek vir dié doel is om die kerk te posisioneer sodat prioriteite gestel kan word vir effektiewe bestuur (doelmatigheid en doeltreffendheid). Die proses om dit te doen, vorm deel van die detail in artikel 2 
en bestaan uit die formulering van die volgende: 'n visie, missie, institusionalisering, bepaling van die konteks (samelewing) en die behaling van resultate om uitkomste te bereik (Manning 1997:1-7). Identiteit dui op die dinge/mense/instansies waarmee jy identifiseer (Van der Walt 1999:51). In die geval van die kerk, sou ons kon sê dat dit nie primêr daaroor gaan "Wie ons is nie", maar "Wie s'n ons is". In Bybelse terme, lyk jy al meer na die God of afgod wat jy aanbid. Dit gaan dus om geloofwaardigheid - of ons met integriteit ons identiteit uitleef, nie net in dit wat ons glo of sê nie, maar veral in wat ons werklik is en doen (Van der Walt 1999:51).

Volgens Hendriks (1991:134-148) is die kerk se identiteit direk te verbind aan 1 Petrus 2:9. Uit hierdie gedeelte is die volgende vier sake in verband met die gemeente se identiteit duidelik: "Wie zij is" - 'n uitverkore volk en 'n koninklike priesterdom; "Tot wie zij behoort" - God se eiendom; "Waar zij vandaan komt" deur die roeping van God; "Wat haar opdracht is" - die verkondiging van die verlossingsdade van God. Hierdie identiteitskonsep is verantwoordelik vir die ontwikkeling van 'n klimaat in 'n gemeente waar alle lidmate gesien word as subjekte waarin gesamentlike beraad (besluitneming) normaal is.

Binne die projekbestuursmodel word daar ruimte gemaak dat die kerk (elke gemeente) as deel van die deelnemende bestuursfilosofie haar eie identiteit kan definieer. Dit word gedoen deur die formulering van 'n eie unieke visie, missie en waardesisteem (oortuigings). Die eie identiteit word tot uitvoer gebring deur ' $n$ deurdagte doelstelling en doelwitte te formuleer en dan in planne gestalte daaraan te gee. Om die gemeente te posisioneer vir bogenoemde behoort konkrete grondslae vir 'n bedieningspraktyk geformuleer te word. Die kerk het 'n behoefte aan 'n duidelike strategie vir haar bedieningspraktyk. Manning (1997:1) sê die volgende: "Businesses fail because they don't know where they are going or they don't move effectively toward their goal. In other words, either their strategy is poorly conceived or unclear, or it is poorly implemented". Hierdie stelling is net so waar vir die kerk. Dit is belangrik om te verstaan wat met strategie bedoel word.

Strategy is the continuous stream of thinking and action which keeps a company (the church) in harmony with its changing environment. Creating a winning strategy is a logical, structured process. There are five key building blocks, each with a specific purpose. The thinking that goes into this framework can be cascaded down through the organisation, with only the values remaining constant at each level.

(Manning 1997:1) 
Hierdie strategie word aan die hand van ' $n$ diagram verduidelik en gee ' $n$ beeld van die strategie oor die volle spektrum van die organisasie of gemeente (Diagram 1.1):

Diagram 1.1 Die grondslae van 'n strategie

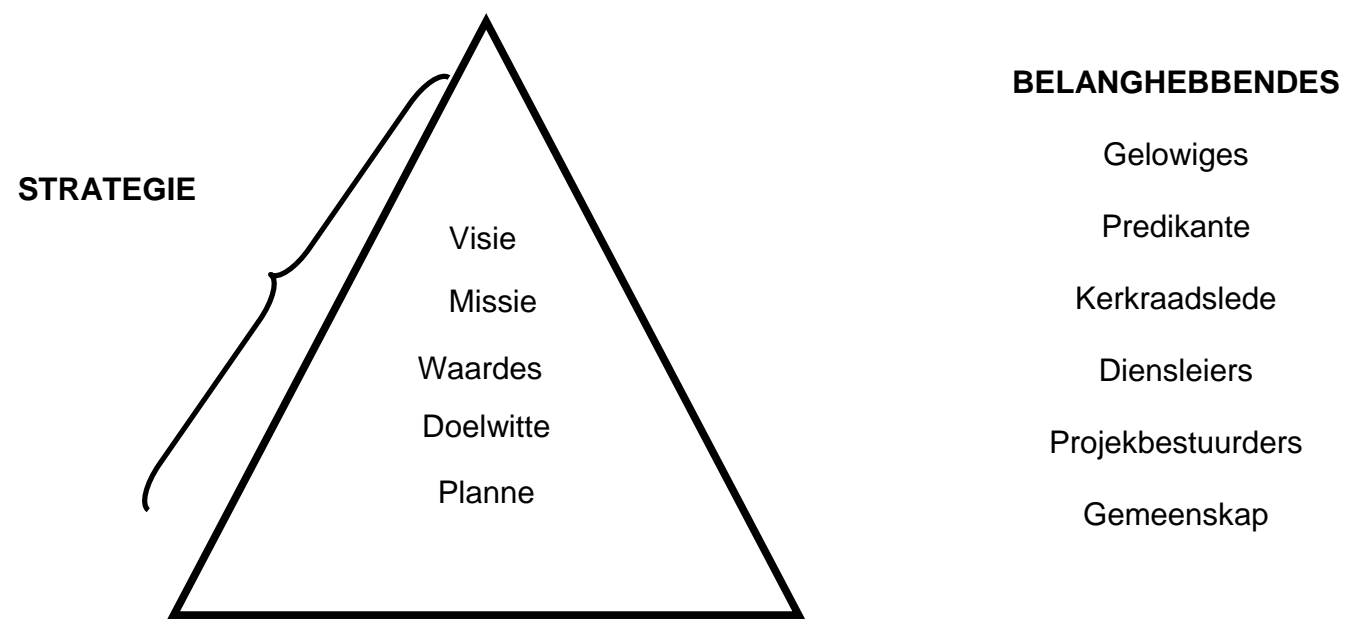

Bron: Aangepas uit Manning (1997); Kroon (1995); Marx et al (1998)

- $\quad$ Visie

Die visie (droom) van die gemeente beskryf waar sy haar oor 'n aantal jare gaan bevind. Visie omvat ' $n$ waagmoed en versiendheid oor wáárheen die gemeente op pad moet wees en wat om te doen om dié doel te bereik (Luecke \& Southhard 1986: 28, 48-51; Kroon 1995:142). "Your vision describes the way you imagine your company to be sometime in the future. It tells people what you aim to be, and therefore where they should concentrate their efforts. Where we're going ... Our dream of the future" (Manning 1997:2; Barna 1992:17-36, Charlton 1992:47$61)$.

\section{- $\quad$ Missie}

Die missie dui die oorkoepelende bestaansdoel van die gemeente in terme van die aard en omvang van die huidige en toekomstige bedieninge en dienste as geloofsgemeenskap, aan (Wagner 1984:141-164; Kroon 1995:142). "Your mission defines your company's business, and describes what you'll do to succeed in that business. The task we set ourself, the business we're in" (Manning 1997:2; Constantiakruin (1998); Aasvoëlkop (1994). 


\section{- Waardes}

Waardes is die reëls waarvolgens 'n mens leef. Waardes bepaal gedrag. "Values are fundamental beliefs or principles that tell people ... what rules we live by ... what counts around here ... or what we pay special attention to" (Manning 1989:3). Waardes is 'n breë geneigdheid om 'n bepaalde toedrag van sake te verkies. Dit het met gevoelens en emosie, met wat goed en sleg is, te doen. Waardes word deur 'n bepaalde etos, credo of geloofsbelydenis bepaal (Kroon 1995:524; Manning 1997:2; Constantiakruin (1998); Aasvoëlkop (1994).

\section{- Doelwitte}

Doelwitte is die eng omskrewe prestasies of die resultate wat oor die korttermyn bereik wil word (Kroon 1995:125). "Objectives are the targets you aim for. They describe what we want to achieve, by when, at what cost" (Manning 1997:5; Constantiakruin (1998); Aasvoëlkop (1994)).

\section{- Planne}

Planne dui aan watter aktiwiteite uitgevoer moet word, watter hulpbronne toegedeel en watter beleid, programme, skedules, prosedures, en metodes gevolg moet word (Marx et al 1998:280-283; Kroon 1995:111, 124-127). "Plans highlight priorities. Plans tell people, how we'll reach our objectives" (Manning 1997:5-6; Constantiakruin (1998); Aasvoëlkop (1994).

\section{DIE GEMEENTE AS BESTUURSOMGEWING}

Die gemeente as bestuursomgewing kan beskou word as 'n skepping van haar eie omgewing deurdat die bates, inkomste, probleme, geleenthede en voortbestaan daarvan grootliks van die omgewing afhanklik is. Veranderinge in die gemeentelike situasie en daarbuite, dwing bestuur voortdurend om aanpassings in die gemeente te maak. ' $n$ Wisselwerking tussen die gemeente en sy omgewing bepaal grootliks hoe die gemeente as bestuursomgewing organisatories daar uitsien en funksioneer. Bestuur sal egter daarteen moet waak dat sekere omgewingsinvloede oorbeklemtoon en ander weer verontagsaam word. Die bestuursomgewing waarin die kerk haar bevind, is die volgende: die gemeente met haar aktiwiteite - mikro-omgewing, markomgewing, makro-omgewing en die internasionale omgewing (Diagram 1.2). 
Diagram 1.2 Die Bestuursomgewing in perspektief

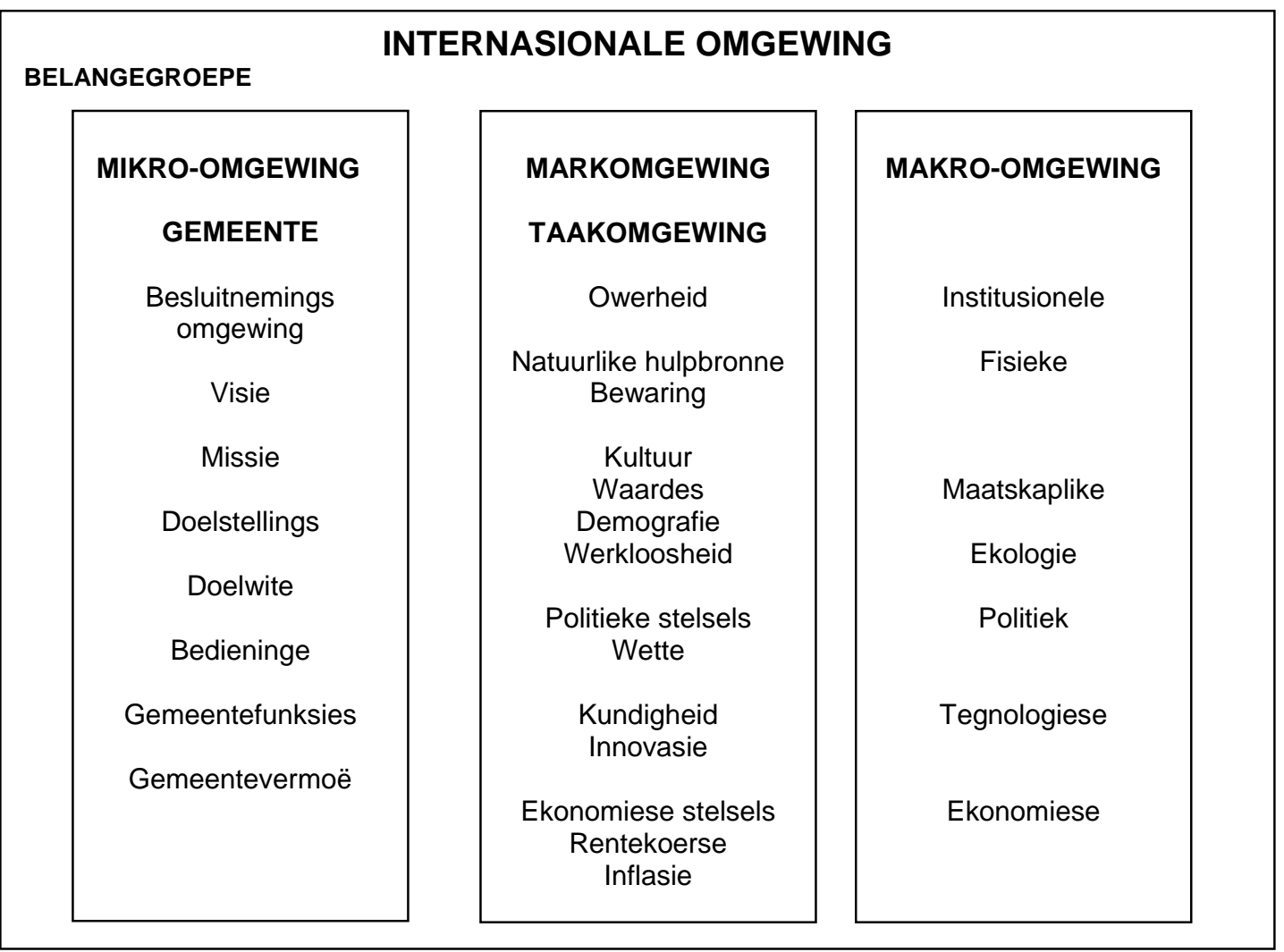

Bron: Aangepas uit Kroon 1995:52 \& Jones et al 2000:78

\section{PROJEKBESTUURSFILOSOFIE}

Talle organisasies het projekbestuur begin toepas om probleme rakende verandering aan te spreek. Projekbestuur per se kan egter nie die bestuursverandering bewerk wat verlang word nie.

Die beginsel van bestuur deur middel van projekte het die antwoord gebied. Hierdie beginsel integreer gevolglik ander areas van bestuur in die soeke na oplossings. Die totale bestuursomgewing word in berekening gebring en die toepaslike bestuurshulpmiddel of middele in kombinasies met mekaar, word geïmplementeer. Die gemeente behoort na aanleiding van bogenoemde onder andere ten minste die volgende vrae te vra: Wat is die gemeente se prioriteite? Wat is die gemeente se doelstellings en doelwitte? Wat moet gedoen word om die doelstellings en doelwitte te bereik? Hoe beïnvloed die verskillende projekte die gemeente se ander dienswerk? Watter gawes, vaardighede ("skills") is nodig om die dienswerk te doen en te voltooi? Hoeveel lidmate is nodig om die werk te voltooi? Wat is nodig om bogenoemde deurlopend te kan doen? 
Bestuur deur middel van projekte spreek hierdie probleme aan, aangesien dit na die gemeente as 'n geheel kyk. Hierdie bestuursbeginsel is nie net doelwitgeoriënteer nie, maar kombineer doelwitbestuur met alle ander bestuursbehoeftes wat in die gemeente mag voorkom. Rudolph Boznak (1999) som die saak as volg op:

For these reasons, management by projects is emerging as a key tool - both for improvements in efficiency and also for business change as it helps ensure that resources are aligned with strategic objectives. Management by project provides the means of balancing and meeting the often conflicting goals of both project and resource management.

Boznak (1999)

Die verloop van die proses: Die volgende elemente van die proses gee ' $n$ aanduiding van hoe 'n voorlopige proses in 'n gemeente behoort te verloop. Die bestuur (die kerkraad en projekbestuurder) formuleer doelwitte wat die behoeftes van die gemeente behoort bevredig en die kernbelanghebbendes (lidmate) tevrede stel. Strategieë word dan ontwikkel wat sal bepaal hoe die planne in werking gestel moet word wat sal verseker dat die doelwitte bereik word. Die implementering van die planne volg hierop en beteken dat projekte geïdentifiseer, gedefinieer en geïmplementeer is. Hulpbronne is toegeken. Tydskale is aan projekte gekoppel. Eienaarskap van projekte is aanvaar. Stelsels en meetinstrumente bepaal of doelwitte bereik is: mylpale, dienste (produkte) gelewer (resultate word teen gestelde planne gemeet). Indien nodig, word veranderinge aan die planne, strategieë en doelwitte aangebring. Hierdie veranderinge moet die organisasie (gemeente) se vordering reflekteer ten einde die oorkoepelende plan te bereik. Rudolph Boznak (1999) som die kompleksiteit van projekbestuur verder soos volg op: "Management by projects is about successfully handling this complexity, and this is extremely important to an organisation's success because what usually determines the success or failure of an organisation is not how brilliant the strategy is, it's how well the plans get executed."

Die rol van die projekbestuurder in 'n gemeente sal by uitstek gekenmerk word deur die volgende: die effektiewe benutting van die beperkte menslike hulpbronne in beperkte tyd en binne die gemeente se begroting. Die projekbestuurder sal as vertrekpunt die vooraf gekose bestuursraamwerk moet 
benut waaruit hy/sy dan projekte in prioriteitsvolgorde sal moet saamstel en bestuur. Die projekte se prioriteite moet so gekies word, dat die projek met die hoogste prioriteit die grootste waarde tot gemeentewees toevoeg.

\section{PROJEKBESTUURSRAAMWERK}

Projekbestuur is 'n bestuursbenadering, naamlik: bestuur deur middel van projekte ("management by projects"). Die raamwerk, met die oog op toepassing in die praktyk, voorsien 'n basiese struktuur om projekbestuur te verstaan vir toepassing deur 'n gemeente se projekbestuurder en lidmate betrokke by projekte. Die raamwerk waarbinne die projekbestuurder die beginsels van projekbestuur behoort toe te pas, bestaan hoofsaaklik uit drie dele: die Projekbestuurskonteks, die Projekbestuursproses en die Projekbestuurskennisareas (PMBOK 2000). Die projekbestuurder speel 'n kardinale rol in die toepassing van elke element in die raamwerk.

\section{- $\quad$ Die Projekbestuurskonteks}

Hierdie konteks beskryf die omgewing waarbinne projekte uitgevoer en bestuur word. Projekte en projekbestuur se toepassingsgebied is groter as net die van 'n projek per se. Die Projekbestuurskonteks sluit die volgende in: Projekfases en projeklewensiklus, Belanghebbendes by die projek, Organisatoriese invloede, Algemene- en strategiese bestuursinvloede, Sosio-ekonomiese invloede.

\section{- Die Projekbestuursprosesse}

Alle projekte word saamgestel uit verskillende prosesse. 'n Proses bestaan uit 'n aantal opeenvolgende dienste wat een of meer resultate tot gevolg het. Hierdie projekprosesse word uitgevoer deur mense en bestaan uit die volgende: Bestuursprosesse - dit is die prosesse wat die werk wat gedoen moet word, beskryf en organiseer; Produkprosesse - dit is die prosesse wat die produk of diens wat gelewer moet word, definieer en spesifiseer; Projekprosesgroepe bestaan uit:

a. Inisiëringsproses - die aanvaarding van eienaarskap van 'n projek en besluit dat 'n projek kan begin.

b. Beplanningsproses - die opstel van 'n skema of plan waarvolgens die projek sal verloop. 
c. Uitvoeringsproses - die koördinering van al die bronne om die plan uit te voer.

d. Kontroleproses - die monitering en meting van vordering ten einde die gestelde doelwitte te bereik en die doen van korrektiewe stappe indien nodig.

e. Afhandelingsproses - die doen van die nodige stappe en opstel van dokumentasie vir die aanvaarding en aftekening van die voltooide projek.

\section{- $\quad$ Projekprosesinteraksies}

Die interaksies ter sprake, is die verskillende insette wat moet plaasvind om die gevraagde uitsette te lewer. Vir alle insette is daar sekere tegnieke en kennis ("tools") wat die uitsette moontlik maak (PMBOK 2000:27-35).

\section{- $\quad$ Die Projekbestuurskennisareas}

Hierdie areas verteenwoordig die kennis wat benodig word vir die verloop en praktiese toepassing van elke projekproses in elke komponent van elke projek. Die PMBOK (2000:189-191) organiseer hierdie kennisareas in nege projekbestuursareas vir doelmatige en doeltreffende bestuur, naamlik:

\section{- Integrasiebestuur}

Integrasiebestuur behels die bestuur van prosesse om te verseker dat verskillende elemente van die projek na behore gekoördineer word. Dit bestaan uit die volgende: Projekplanontwikkeling - die integrering en koördinering van alle planne in een samevattende dokument; Projekplanuitvoering - die uitvoer van die plan deur die implementering van al die gedokumenteerde aktiwiteite; Veranderingskontrole - die integrering van 'n meganisme om verandering oor die totale projek te koördineer indien nodig (Kerzner 1998:519-593).

\section{- Omvangbestuur ("scope")}

Die bestuur van die omvang van die projek behels dat 'n gekose proses daargestel moet word wat sal verseker dat die projek suksesvol afgehandel word. Dit bestaan uit die volgende: Inisiëring - die magtiging om die projek te begin; Beplanning - die daarstel van 'n geskrewe dokument waarin die omvang duidelik gedefinieer is vir aanvaarding en aftekening; Definiëring van aflewerbares - die 
onderverdeling van die aflewerbare produk of diens in kleiner bestuurbare eenhede (vgl ook Kerzner 1998:225-283).

\section{- Tydbestuur}

Hierdie aspek sluit die prosesse in wat bestuur moet word vir die voltooiing van die projek op die ooreengekome tyd, volgens spesifikasies en binne die begroting. Dit bestaan uit die volgende: Die ontwikkeling van 'n skedule - wat die volgende insluit: menslike hulpbronne, aktiwiteite, tydskale en kontrolemeganismes (vgl ook Kerzner 1998:319-351).

\section{- Kostebestuur}

Hierdie aspek sluit die prosesse in wat bestuur moet word vir die voltooiing van die projek binne die goedgekeurde begroting. Dit bestaan uit die volgende: Beplanning van hulpbronne benodig - die bepaling van die hoeveelheid mense, toerusting en materiaal wat benodig sal word om die projek te voltooi; Kosteberekening - die totale koste verbonde aan al die bronne benodig (vgl ook Kerzner 1998:786-825).

\section{- Kwaliteitsbestuur}

Hierdie aspek sluit die prosesse in wat bestuur moet word wat sal verseker dat die projek by aflewering aan die behoeftes van alle belanghebbendes sal voldoen soos aanvanklik ooreengekom. Dit bestaan uit die volgende: Kwaliteitsbeplanning - die stel van standaarde en die voldoening daaraan en Kwaliteitsversekering - die deurlopende koördinering en evaluering van die projekverloop en voldoening aan gestelde standaarde (vgl ook Kerzner 1998:1041-1086).

\section{- $\quad$ Menslike hulpbronbestuur}

Hierdie aspek sluit die prosesse in wat bestuur moet word. Dit bestaan uit die volgende: Organisatoriese beplanning - dit is die identifisering, dokumentering en toewys van take en rolle, verantwoordelikhede en rapporteringsverantwoordelikhede en kanale. Die volgende is belangrik: Aanstellings van personeel - die volg van die korrekte prosedures vir die aanstel van mense benodig vir spesifieke projektake; Opleiding - die gee van opleiding en ontwikkeling van spesifieke vermoëns ("skills") indien benodig, met die oog daarop om projekresultate te verbeter (vgl ook Kerzner 1998:93-138, 157-206). 


\section{- Kommunikasiebestuur}

Hierdie aspek sluit die prosesse in wat die bestuur van inligting rakende die totale projek behels. Dit bestaan uit die volgende: Beplanning van kommunikasie - die bepaling van die kommunikasiebehoeftes van die belanghebbendes - wie het watter inligting nodig, wanneer is dit nodig en hoe gaan gekommunikeer word; Statusverslae - die deurlopende opstel en byhou van die projek se status deur vorderingsverslae en rapportering (vgl ook Kerzner 1998:267-283).

\section{- Risikobestuur}

Risikobestuur is ' $n$ deurlopende proses van identifisering en analisering van risiko's om te verseker dat foute en vertragings geminimaliseer word en dat suksesse gemaksimaliseer word. Dit bestaan uit die volgende: Risikobestuurder - die enigste manier om risiko's effektief te bestuur is om 'n ervare risikobestuurder aan te stel (vgl ook Kerzner 1998:867-898).

\section{- Kontrak- en uitvoeringsbestuur ("procurement management")} Hierdie aspek sluit die prosesse (regsprosesse) in wat bestuur moet word wat verantwoordelik is vir die kontraktering van mense en dienste wat die organisasie nie intern kan voorsien nie. Dit bestaan uit die volgende: Kontrakadministrasie dit behels die opstel van 'n databasis van wie moontlik gekontrakteer gaan word, aanvra van kwotasies, keuse van alternatiewe kontrakteurs, bou van verhoudings met kontrakteurs, sluit van kontrakte en bestuur van kontrakteurs (vgl ook Kerzner 1998:1093-1113).

\section{DIE PRAKTYK}

Die toepassing van projekbestuur as bestuursbeginsel mag nie gesien word as ' $n$ kitsoplossing vir die probleme van die kerk nie. Tegniek, hulpmiddels en metodiek, van watter aard ookal, gaan nie die kerk verander nie. Projekbestuur is hoogstens ' $n$ waardevolle bestuurshulpmiddel in diens van die evangelie. Projekbestuur is in dié proses ' $n$ ordelike en planmatige gedokumenteerde proses. Hierdie proses het onder andere die volgende ten doel: identifiseer die probleem of behoefte, bepaal dit wat nodig is om die behoefte bevredigend op te los, evalueer alternatiewe oplossings en maak 'n keuse vir die beste een, beplan die proses, lei mense op en implementeer die proses (Reis 1992:10-15). Projekbestuur soos gedefinieer (PMBOK 2000:6) word as uitgangspunt geneem om generiese grondslae te formuleer. Projekbestuur sentreer rondom vier 
kernfunksies (Diagram 1.3) - dit is die bestuur van die produk/diens/doelwit, tyd, koste en arbeid (dienswerk).

Diagram 1.3 Kernfunksies van projekbestuur

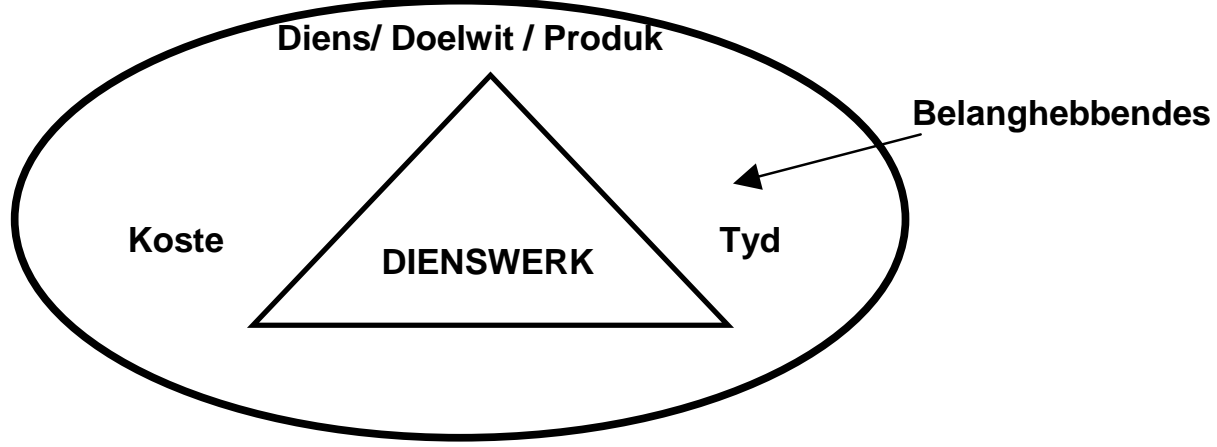

Bron: Aangepas uit Sparius (2001)

Elke projek moet altyd alle belanghebbendes in ag neem. Hierdie kernfunksies word aangevul deur die integrering van die nege kennisareas hierbo genoem. Projekbestuur is die bestuurshulpmiddel wat gebruik word om strategiese verandering teweeg te bring - veral nadat behoeftes geïdentifiseer is. Die projekbestuurder is 'n belangrike rolspeler in die totale proses van die projek se verloop en in elke fase van die projek se siklus. "The project manager is a powerful single point of integrative responsibility" (Sparius 2001; Gray \& Larson 2000:261-282; Maylor 1999:23-25). Hierdie beginsel beteken dat daar 'n balans moet wees tussen verantwoordelikheid en outoriteit ("accountability and authority") (Kerzner 1998:232-240, 243-24).

\section{- Projeksiklus}

Die generiese projeklewensiklus word hier aan die hand van 'n diagram gegee (Diagram 1.4). (Vir die praktiese toepassing van die siklusse 0-5, kyk Van den Berg 2003.) Die projekbestuurder behoort in die toepassing van die beginsels van bestuur deur projekte altyd te onthou "You don't demand respect, you earn it; successful project managers rely more on personal influence and earned authority than on formal authority" (Sparius 2001), want die projekbestuurder werk deurlopend met mense as spesialiste op hulle afsonderlike gebiede.

Die basiese prosesse (Diagram 1.4), wat ook die projeksiklus is, wat in projekbestuur gebruik word, word as volg omskryf: 


\section{- Konsepfase}

Die projek se omvang moet tydens dié fase in detail gedefinieer word. Alle elemente in die konseptuele fase word hier verfyn. Die identifisering van alle bronne wat benodig gaan word, moet hier in detail gedoen word, naamlik mense en realistiese parameters wat 'n invloed op die tyd, koste en die projekverloop kan hê (Adendorff \& De Wit 1997:157; Kerzner 2000:75).

\section{Diagram 1.4 Projeklewensiklus}

\begin{tabular}{|c|c|c|c|c|}
\hline & & & $\begin{array}{c}\text { Fase } 5 \\
\text { Kontrole } \\
\downarrow\end{array}$ & \\
\hline Fase 0 & Fase 1 & Fase 2 & Fase 3 & Fase 4 \\
\hline Behoefte/Konsep/Definisie & Inisiëring & Beplanning & Uitvoering & Afhandeling \\
\hline Mylpaal 1 & Mylpaal 2 & Mylpaal 3 & Mylpaal 4 & Mylpaal 5 \\
\hline Basiskontrak & Basiskontrak & Basiskontrak & Basiskontrak & Basiskontrak \\
\hline
\end{tabular}

Bron: Aangepas uit Adendorff \& De Wit (1997)

\section{- Inisiëring van die projek ("initiate")}

Hierdie fase behels bloot die goedkeuring deur die gemeente om met die volgende belangrike fase voort te gaan (PMBOK 2000:30).

\section{- Beplanning van die projek ("plan")}

Hierdie fase (waarskynlik die belangrikste) is die begin van die operasionele in die projekverloop. Dit dien grootliks as 'n toetsfase om te bepaal of alle planne in plek is. Daar word bevestig dat alle planne opgedateer is, menslike hulpbronne aangestel is, ander hulpbronne bevestig is, kontrakte geteken is, stelsels en prosedures gefinaliseer is en die projekbestuurder bevestiging het om voort te gaan (Adendorff \& De Wit 1997:158; Kerzner 2000:77; PMBOK 2000:30).

\section{- Uitvoering van die projekplan ("execute")}

Hierdie fase is die begin van die operasionele deel van die projek. Die planne word in werking gestel deurdat alle aktiwiteite uitgevoer word. Deurlopende projekkontrole word gedoen en statusverslae oor die projekverloop word aan alle belanghebbendes gekommunikeer soos ooreengekom. Hierdie fase vra ook dat deurlopende evaluering van mense, kontrakteurs, stelsels, prosedures en planne sal plaasvind (Adendorff \& De Wit 1997:158; Kerzner 2000:77). 


\section{- Kontrolering van die projekverloop ("control")}

Hierdie fase behels deurlopende kontrole oor die volgende fases: beplanning, uitvoering (operasionele) en die afhandelingsfase. Die kontrolefase is ' $n$ interaktiewe fase wat moontlike verandering oor die hele projek moet fasiliteer wat die volgende kan behels: verandering van skedule, begroting en spesifikasies. Kontrole oor rapportering van kwaliteit, risiko's en vordering, is deel van hierdie fase (PMBOK 2000:32).

\section{- $\quad$ Afhandeling van die projek ("Close-out")}

In hierdie fase vind die administratiewe afhandelingsproses plaas. Alle belanghebbendes word ingelig oor die projek se status, dat dit voltooi is en dat die projek afgeteken kan word soos gekontrakteer. Die produk/diens word afgelewer volgens spesifikasies en die nodige finale kwaliteitsinspeksie word gedoen. 'n Finale statusverslag oor die suksesvolle afhandeling van die projek, word aan alle belanghebbendes gestuur (Adendorff \& De Wit 1997:158-159; Kerzner 2000:77-78).

By die toepassings van die beginsels van projekbestuur, soos hierbo omskryf, is dit noodwendig dat daar altyd integrering met ander bestuursareas en -tegnieke sal wees. Die projekbestuurder sal daarom veral ook toegerus moet wees in die algemene en strategiese bestuurstegnieke. Strategie verwys na 'n plan wat die hulpbronne aan die toekomstige moontlikhede in die kerklike omgewing (mark) verbind (Diagram 1.5).

\section{Diagram 1.5 Geïntegreerde Projekbestuursmodel}

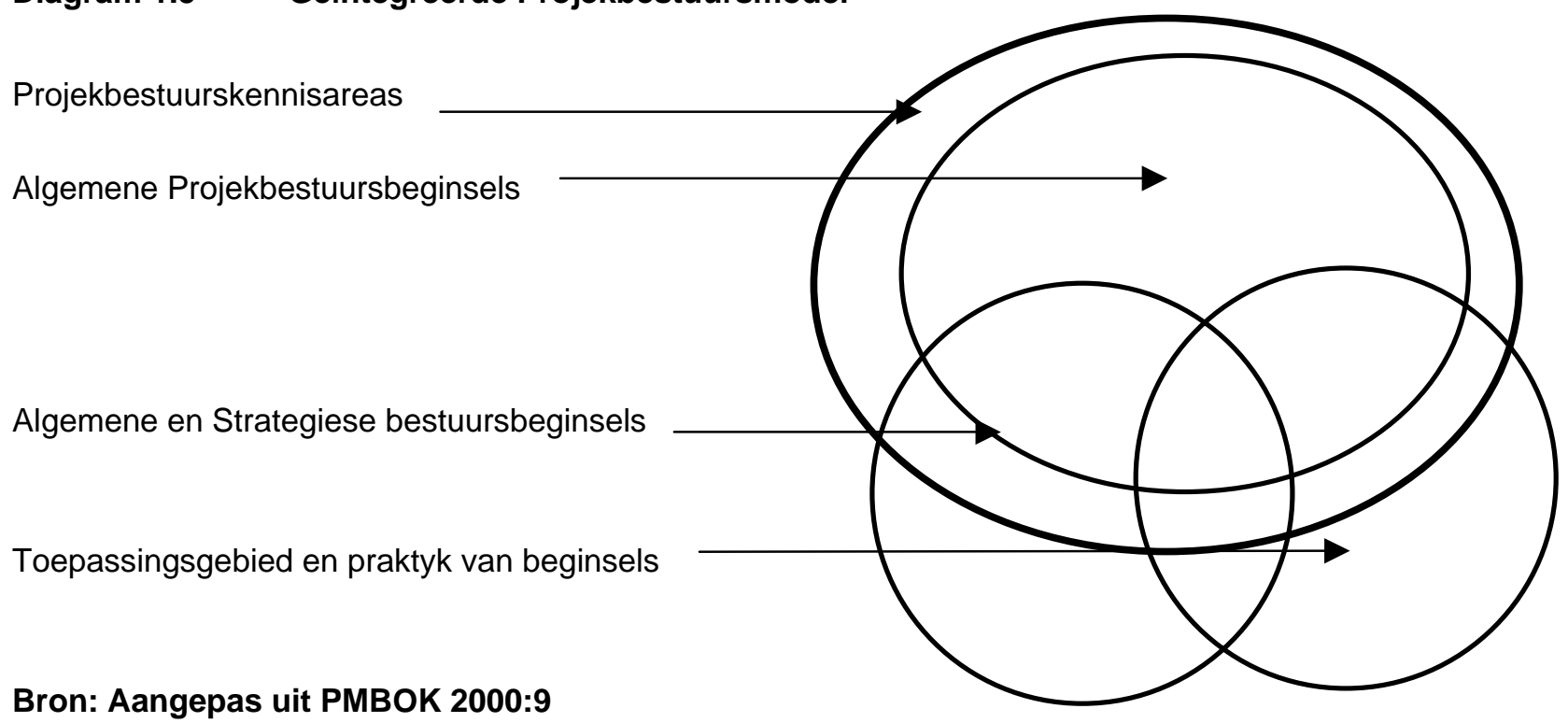




\section{GENERIESE RIGLYNE VIR 'N BESTUURSRAAMWERK}

Die oogmerk is om breë generiese bestuursgrondslae neer te lê om met behulp van funksionele en praktiese projekbestuursbeginsels 'n model vir effektiewe bestuur te ontwerp. Vanuit die gemeente as die kommunikatiewe gemeenskap is gekyk na die funksies van die kerk. Daar is na die gemeente gekyk vanuit die perspektief van die kommunikasie van die evangelie. Kerkbestuur is daarom nie maar net ' $n$ losstaande handeling nie, maar verteenwoordig ' $n$ doelmatige handeling wat daarop ingestel is om die doelstellings en doelwitte wat deur deelnemende besluitneming vasgestel is, te bereik.

'n Strategie vir die implementering van die konkrete grondslae, visie, missie, waardes, doelwitte en planne is gevolglik geformuleer (diagram 1.1). Die gemeente se identiteit, aktualiteit, verwerkliking, samelewingsverbande, vernuwing en die deurbreking van formalisme, is in ag geneem. Die doelstelling was om die kerk te begin posisioneer om haar roeping te kan uitleef in 'n moderne nuwe tyd/konteks - die postmoderne gemeentesituasie: In die soeke na 'n verstelde bestuurspraktyk, behoort 'n gemeente binne sy samelewings-konteks (Van der Ven 1993:10-12) ondersoek te word. Gemeentes bestaan en funksioneer as deel van 'n samelewing. Die funksionering binne so 'n samelewing is noodwendig onderworpe aan al die geleenthede, beperkings, sterk punte en swak punte van die samelewing.

Die resultaat hiervan is dat ook die empiriese werklikheid van 'n gemeente se situasie deurlopend in berekening gebring is (Pieterse 1993, 169-170; vgl veral Smuts 1995:121-181). Die gemeentelike praxis staan nie los van historiese veranderinge en kulturele en sosiale verskille nie. Vir die doel van hierdie artikel is slegs inligting oor die praktyk van bestuur in gemeentes nagevors, dit is praktykkennis (naas algemene teorie) met die oog op 'n spesifieke gemeentekonteks (Dreyer 1993:223-224; vgl ook Burger 1991:150). 'n Praktykteorie vir die ontwikkeling en vestiging van 'n eie bestuursmodel word aangebied deur 'n interaksie van ekklesiologie en situasie te benut.

\section{VOORDELE VAN PROJEKBESTUUR}

Volgens Kerzner (1992:3) kan die volgende potensiële voordele met effektiewe projekbestuur verkry word: 
- Identifisering van funksionele verantwoordelikhede ten einde te verseker dat alle aktiwiteite uitgevoer word, ongeag die personeelomset.

- $\quad$ Minimering van die deurlopende behoefte van bestuur vir terugvoer of verslagdoening.

- Identifisering van tydsbeperkings vir skedulering.

- Identifisering van 'n metodologie vir "afspeel"-analises.

- $\quad$ Meting van taakbehalings of "werk gdoen", teen die beplanning daarvoor.

- $\quad$ Vroegtydige identifisering van probleme en die implementering van regstellende aksies wat vereis mag word.

- Verbeterde projekramingsvermoë, veral met toekomstigde projekte, aangesien die projekgeskiedenis van vorige projekte as hulpmiddel sal dien.

- Wanneer 'n doelwit nie bereik kan word nie, of laat gaan wees, sal hierdie inligting vroegtydig reeds beskikbaar wees.

- $\quad$ Take wat normaalweg nie deur die tradisionele organisasiestrukture hanteer kon word nie, kan aangepak en suksesvol afgehandel word.

- $\quad$ Eenmalige take of aktiwiteite kan aangepak word, met die minimum impak op die organisasie se roetine of besigheid (Kerzner 1992:29).

\section{SAMEVATTING}

In hierdie artikel is 'n projek en projekbestuur gedefinieer en bespreek. Die kriteria vir 'n suksesvolle projek is gegee, asook die belangrikheid, groei en voordele van die projekbestuursdissipline in die kerklike omgewing. Die belangrikste gedeelte in artikel 1 is die identifisering van die projekbestuurslewensiklus met die volgende vyf prominente fases in dié siklus, naamlik: projekinisiëringsfase, projekbeplanningsfase, projekuitvoeringsfase, projekkontrolefase, en projekafsluitingsfase. Dit is hoofsaaklik op hierdie vyf fases van 
projekbestuur waarop die projekbestuursmodel vir 'n makrogemeente gebou word (kyk van den Berg 2003).

\section{Literatuurverwysings}

Adendorff, S A \& De Wit, P W C (eds) 1997. Production and operations management: A South African perspective. $2^{\text {nd }}$ ed. Johannesburg: Thomson.

Archibald, R D 1976. Managing high-technology programs and projects. Toronto: John Wiley \& Sons.

Barna, G 1992. The power of vision: How you can capture and apply God's vision for your ministry. California: Regal Books.

Boznak, R 1999. Management by projects versus project management: A comparison in improving business performance through management by projects. PM Network, January 1996. Internet: Available: http://www.amsusa.com/whitepaper.htm1. Access: 13 July 1999. (last updated.)

Buitendag, J 1994. Strategiese bestuur: Die missiestelling van 'n onderneming as komponent van die strategiese bestuursmodel soos toegepas op 'n Gereforrmeerde Kerk. MCom-skripsie, Randse Afrikaanse Universiteit.

Burger, C 1991. Die dinamika van 'n Christelike geloofsgemeenskap: Nuut gedink oor gemeentes. Kaapstad: Lux Verbi.

Charlton, G 1992. Leadership: The human race. A guide to developing leadership potential in Southern Africa. Kenwyn: Juta.

Constantiakruin: Kyk Nederduitse Gereformeerde Kerk.

Cummings, T G \& Worley, C G 1993. Organization development and change, 5th ed. San Francisco: West Publishing Company.

Deacon, T 1997. The anatomy of a project manager. ProjectPro. Pretoria: Project Publishing.

Deacon, T 1998. Habits of highly effective project managers. ProjectPro. Pretoria: Project Publishing.

Dingemans, G D J 2000. De stem van de Roepende: Pneumatheologie. Kampen: Kok.

Dinsmore, P C (ed) 1993. The AMA handbook of project management. New York: Amacon.

Dreyer, J S 1993. Die moderne gemeente en haar funksionering: Die belang, aard en benutting van praktykkennis, in Dreyer, J S \& Pieterse, H J C (reds), Die moderne gemeente en haar funksionering. Pretoria: Verba Vitae.

Gido, J, \& Clemments, J P 1999. Successful project management. Ohio: ITP.

Gray, C F \& Larson, E W 2000. Project management: The managerial process. Toronto: McGraw-Hill.

Greenleaf, R K 1991. Servant leadership: A journey into the nature of legitimate power and greatness. New York: Paulist Press.

Heitink, G 1993. Praktische Theologie: Geschiedenis - theorie - handelingsvelden. Kampen: Kok.

Heitink, G 2000. Het publieke karakter van de kerk. Skrif en Kerk 21(2), 260-274.

Hendriks, J 1991. Een vitale en aantrekkelijke gemeente: Model en methode van gemeenteopbouw. Kampen: Kok. 
Jones, G R et al 2000. Contemporary management. Boston: McGraw-Hill.

Kerzner, $\mathrm{H}$ 1992. Project management: A systems approach to planning, scheduling and controlling. 4th ed. New York: Van Nostrand Reinhold.

Kerzner, H 1998. Project management: A systems approach to planning, scheduling and controlling. 6th ed. New York: John Wiley \& Sons.

Kerzner, H 2000. Applied project management: Best practices on implementation. New York: John Wiley \& Sons.

Knutson, J \& Bitz, I 1991. Project management: How to plan and manage successful projects. New York: AMACOM.

Kroon, J (red) 1995. Algemene bestuur. 3de uitg. Pretoria: Kagiso-Tersiêr.

Lindgren, A J 1965. Foundations for purposeful church administration. Nashville, TN: Abingdon.

Luecke, D S \& Southhard, S 1986. Pastoral administration: Integrating ministry and management in the church. Waco, TX: Word Books.

Manning, T 199. Spirit of the entrepreneur. Parkview: SA Success.

Marx, S et al 1998. Ondernemingsbestuur. Pretoria: J L van Schaik.

Meredith, J R \& Mantel, S J (jnr) 2000. Project management: A managerial approach. 4th ed. New York: John Wiley and Sons.

Maylor, H 1999. Project management. 2nd ed. Johannesburg: Pitman Publishers.

Nederduitse Gereformeerde Kerk, Gemeente Aasvoëlkop. 1994 Kerkraadskommissieverslag: Strategiese beplanningsdokument. Ongepubliseerd.

Nederduitse Gereformeerde Kerk, Gemeente Constantiakruin. 1998 Kerkraadskommissieverslag: Strategiese beplanningsdokument. Ongepubliseerd.

Newbold, P C 1998. Project management in the fast lane: Applying the theory of constraints. Washington, DC: St Louis Press.

Oosthuizen, P 1994. The silent revolution: Project management how to make business work - The project management approach. Arcadia: PM Publishers.

Pieterse, H J C 1991. Die wetenskapsteoretiese grondslag van die praktiese teologie. Praktiese teologie in Suid-Afrika 6(1).

Pieterse, H J C 1993. Inleiding/Introduction, in Dreyer, J S \& Pieterse, H J C (reds), Die moderne gemeente en haar funksionering. Pretoria: Verba Vitae.

PMBOK: See Project Managers Institute Standards Committee.

Project Managers Institute Standards Committee 2000. A guide to the project management body of knowledge. Pennsylvania USA: Project Management Institute.

Reis G 1992. Project management demystified: Todays tools and techniques. London: E \& F N Spon.

Rossouw, G J (ed) 1995. Life in a postmodern culture. Pretoria: HSRC Publishers.

Smuts, M 1995. Ontwikkeling van 'n gemeentelike bedieningsmodel. DD-proefskrif, Universiteit van Pretoria.

Sparius, A 2001. Project management overview: Principals of project management. A seminar presented at the Momentum Auditoriom, Centurion.

Van den Berg, A A 1998. Die plek en funksie van bestuur in die kerk. MComverhandeling, Potchefstroomse Universiteit vir $\mathrm{CHO}$. 
Van den Berg, A A 2003. Die plek en funksie van 'n projekbestuursmodel in 'n makrogemeente. HTS 59(4), 1413-1423.

Van der Walt, B J 1999. Naby God. Christen en die kerk op die drumpel van spiritualiteit. Potchefstroom: IRS. (Reeks F2, nr 74, Lente 1999.)

Van der Waldt, G \& Knipe, A 1998. Project management for strategic change and upliftment. Johannesburg: ITP.

Van der Ven, J A 1993. Ecclesiologie in context. Kampen: Kok.

Van Wyk, J T J 1995. Projekbestuur vir inligtingstelsels: 'n Geïntegreerde prosesmodel. MBA skripsie, Universiteit Pretoria.

Vos, C J A 2000. Kerk en teologie in die jaar nul. Skrif en Kerk 21(1), 172-190.

Wagner, C P 1884. Leading your church to growth: The secret of pastor/people partnership in dynamic church growth. California: Regal Books. 